\title{
MENDISABILITASKAN MANUSIA \\ MERAJUT KESETARAAN AKSESIBILITAS RUMAH IBADAH BAGI KAUM DIFABEL
}

\author{
M. IlhamNurhakim \\ ilham.nurhakim@ymail.com \\ UniversitasNegeri Malang
}

\begin{abstract}
Abstrak
Penyandang disabilitas adalah sebagian orang yang mempunyai hambatan personal terkait dengan kondisi fisik, mental intelektual, atau sensorik dalam jangka waktu yang cukup lama. Hambatan hambatan ini diperburuk dengan situasi lingkungan sosial maupun fisik yang tidak mendukung untuk tumbuhberkembang, berpartisipasi dan berperan sosial, serta menjalani penghidupan yang layak sebagai manusia yang bermartabat. Banyak masyarakat yang tidak peduli terhadap kaum difabel, salah satu bentuk ketidakpedulian masyarakat terhadap kaum disabilitas adalah minimnya aksesibilitas kemudahan rumah ibadah bagi kaum disabilitas. Padahal hak bagi kaum difabel ini seharusnya difasilitasi oleh berbagai kalangan di masyarakat.Pelanggaran Hak Asasi Manusia (HAM) ini dimulai ketika hak dan kewajiban yang berjalan tidak seimbang, karena setiap manusia mempunyai hak kodrat yang dibawa oleh manusia sejak dalam kandungan hal itu merupakan hak fundamental yang dimiliki oleh setiap manusia sejak lahir yang diberikan oleh Tuhan yang Maha Esa, yang melekat pada setiap manusia sebagai makhluk individu dan sebagai makhluk sosial. Sehingga kaum disabilitas seharusnya mempunyai hak untuk tidak diperlakukan secara diskriminatif dalam segala aspek kehidupan dalam bermasyarakat. Dengan cara memberikan fasilitas dan aksesibilitas yang dibutuhkan oleh masyarkat difabel demi memberi kesetaraan, kenyamanan dan kesejahteraan untuk kaum disabilitas. Memberikan tempat ibadah yang inklusi membuat semua golongan lapisan masyarakat bisa untuk datang ke masjid tanpa adanya perbedaan. Masyarakat seharusnya ikut andil serta merta dalam menciptakan sebuah tatanan generasi baru yang inklusi, meleburkan segala sekat pemisah yang menghalangi hak antara difabel dan masyarakatnormal seperti biasa.
\end{abstract}

Kata kunci: Disabilitas, HAM, Aksesibilits Rumah Ibadah

\section{Prolog: Ham Dan Disabilitas Di Indonesia}

Isu penyandang cacat yang awalnya tertimbun limbo sejarah kini mencuat kembali kepermukaan.Hal tersebut, terlihat dari bertambahnya jumlah penyandang cacat di Indonesia. Bahkan badan pusat statistika (BPS) pada tahun 2010 mencatat ada sebanyak 9.040.000 juta jiwa atau 10\% dari total penduduk di Indonesia adalah penyandang cacat ${ }^{1}$.

\footnotetext{
${ }^{1}$ BadanPusatStatistika. 2010. JumlahPenyandangcacat di Indonesia. Jakarta
} 
Penyandang cacat merupakan orang yang memiliki kekurangan fisik, mental intelektual, atau sensorik dalam jangka waktu yang cukup lama ${ }^{2}$. Namun Kini sematan nama (penyandang cacat) mulai dibenahi, oleh para akademisi, ormas (organisasi masyarakat, dan para birokrat. Memberikan pergeseran paradigma lama ke dalam paradigma yang baru. Awalnya bernama penyandang cacat, kini berubah menjadi "disabilitas atau difabel" namun mempunyai makna yang sama.Difabel merupakan singkatan dari different abillity people, yang berarti perbedaan kemampuan dengan manusia regular (manusia normal) ${ }^{3}$.Eufemisme (penghalusan kata) ini bertujuan untuk mengurangi kata yang menyinggung, sebab difabel mempunyai sensitifitas yang sangat tinggi, dan tujuan intinya adalah mengangkat harkat martabat para difabel. Tidak dapat dipungkiri, selama ini masih banyak orang difabel yang memperoleh perlakuan yang diskriminatif secara struktural, yang dilakukan oleh keluarga, masyarakat bahkan negara ${ }^{4}$

Berkaitan dengan masyarakat yang ada diIndonesia,menganggap difabel orang yang mempunyai derajatnya paling rendah. Bahkan mentaskhir(menghina) para difabel, terbukti dari banyak isu yang di lontarkan, bahwa difabel merupakan cetakan gagal (Fail Production), mitos yang beredar di kalangan masyarakat menilai difabel merupakansebuah kutukan, karma yang di terima. Anggapan nenek moyang terdahuluyang mebuat suatu kesalahan beratdan tidak dapat ditoleransi, sehingga generasi anak cuculah yang harus menaggung bebanya sebagi orang cacat. Hal tersebut, lumrah disematkan kepada orang-orang yang cacat, sehingga mereka sukar (malu) untuk datang berkerumun (kumpul) di tempat umum seperti tempat ibadah, yang seharusnya di peruntukan untuk semua orang tanpa terkecuali. Sungguh sangat ironi kita tinggal di negara hukum namun masih banyak tindakan diskriminasi, yang di layangkan kepada saudara kita kaum minoritas (difabel).

\footnotetext{
${ }^{2} \mathrm{Hal}$ inimenghambatpartisipasipenyandangcacatuntukikutberpatisipasidalamsebuahkegiatan. Sholeh, Akmad.2016.AksesibilitasPenyandangDisabilitasTerhadapPerguruan Tinggi. Yogyakarta: LKIS Hal 22 ${ }^{3}$ Aziz, Safrudin. 2014. Perpustakaan Ramah Difabel. Yogyakarta: Ar-Ruzz Media. Hal 5

${ }^{4}$ Tidak sedikit kebijakan maupun isu di masyarakat justru mendiskreditkan para difabel. Aziz, Safrudin. 2014. Perpustakaan Ramah Difabel. Yogyakarta: Ar-Ruzz Media Hal 6
} 
Hak untuk tidak diperlakukan diskriminatif bagi kaum difabel. Pelanggaran Hak Asasi Manusia (HAM) dimulai ketika hak dan kewajiban tidak berjalan secara seimbang. Apabila suatu kewajiban untuk memberikan hak kepada orang lain tidak dilakukan maka disitulah terjadi pelanggaran $\mathrm{HAM}^{5}$. Maka dari itu perlunya penegakan HAM kepada kaumdifabel. Hak kodrati yang dibawa oleh manusia sejak dalam kandungan ${ }^{6}$, hal tersebut merupakan hak fundamental yang perlu di miliki oleh semua manusia ${ }^{7}$ Hakikat keberadaan dan dasar hak asasi manusaia semata-mata untuk kepentingan manusia itu sendiri ${ }^{8}$, lebih penting dari itu ialah diakui dan dihormatinya human dignitymartabat kemanusian setiap manusia, tanpa membedakan strata, sosial dan status sosialnya ${ }^{9}$.

Lalu pertanyaan yang muncul bagaimana cara mengangkat derajat difabel? Perlunya seperangkat konsep yang berbeda mengenai bagaimana memberikan hak yang semestinya bagi difabel hal tersebut sudah masuk dalam kategori dharuroh (darurat). Bahwa untuk mewujudkan kesamaan hak dan kesempatan bagi penyandang disabilitas menuju kehidupan yang sejahtera, dan tanpa diskriminasi ${ }^{10}$. Perlunya Alla mufakar fihi (hal yang tak terfikirkan), yaitu penyetaraan dengan inklusi memberikan suatu wadah tempat bersama antara orang reguler dan difabel supaya dapat berinteraksi bersama, membangun kerjasama yang disesuaikan terutama dalam masalah beribadah dalam rangka menyempurnakan kehidupan agamanya $^{11}$

\footnotetext{
${ }^{5}$ Samawi, Ahmad. 2007. Pendidikan Hak Asasi Manusia. Jakarta: Direktoral Jendral Pendidikan Nasional Hal 52

${ }^{6}$ Nasution, Bahder J. 2014. Negara Hukum dan Hak Asasi Manusia. Bandung:

Mandar Maju Hal 129

${ }^{7}$ Naning, Ramdlon. 1983. Cita dan Citra Hak-hak Asasi Manusia di Indonesia. Jakarta: Lembaga Kriminolog Universitas Indonesia Hal 7

${ }^{8}$ Effendi, Masyhur.1993. Dimensi/Dinamika Hak Asasi Manusia Dalam Hukum Nasional dan Internasional. Bogor: Ghalia Indonesia

Lebih penting dari itu ialah diakui dan dihormatinya human dignity/martabat kemanusian setiap manusia, tanpa membedakan strata, sosial dan status sosialnya Hal 47

${ }^{9}$ Effendi M \& Evandri Taufani S. HAM Dalam Dimensi/Dinamika Yuridis, Sosial, Politik Dan Proses Penyusunan/Aplikasi HA-KHAM (Hukum Hak Asasi Manusia) Dalam Masyarakat. Bogor: Ghalia Indonesia Hal 69

${ }^{10}$ Tim Indepth Rights PPRBM Yayasan Bhakti Luhur. 2016. Equality Hak-hak Penyandang Disabilitas. Malang: Caesarya Yudiswara

${ }^{11}$ Asrori, Hadi. 2009. HAM Dalam Perspektif Agama Islam. Bandung: Refika aditama Hal 284
} 
Islam sebagai agamarahmatan lil alamin. Agama yang sempurna mengedepankan amal dan kerja bukan wacana dan oral, memberikan kisah inspiratif bagaimana memperlakukan kaum difabel. Melalui panutan kita baginda Rasullah SAW memberikan contoh kepada umatnya.

\section{Memaknai Teguran Allah Kepada Rasul Berkenaan Kaum Difabel}

Islam telah memberikan petunjuk bagaimana memperlakukan kaum difabel, kisah dari Rasulullah SAW. Dapat menjadi pelajaran bagaimana seharusnya kaum difabel mendapatkan hak yang semestinya.

Menurut sebuah riwayat yang disampaikan oleh Ibnu Jarir ath-Thabari, demikian juga diriwayatkan dari Ibnu Abi Hatim, yang diterima dari Ibnu Abbas, Sedang Rasullah menghadapi beberapa orang terkemuka Quraisy, yaitu Utbah bin Rabi'ah, Abu Jahal, dan Abbas bin Abdul Muthalib, dengan maksud memberi keterangan mereka tentang hakikat Islam $^{12}$. Namun tak disangka-sangka ada seseorang yang buta datang kepada Rasul namanya (Abdullah bin Ummi Maktum). Ketika itu masuklah lelaki buta tersebut dan langsung masuk kedalam majelis dengan tangan yang meraba-raba. Abdullah bin Ummi Maktum langsung berseru dengan suara agak keras: "Ajarkanlah kepadaku apa-apa yang telah di ajarkan oleh Allah ajarkan kepadamu". Akan tetapi Nabi SAW berpaling darinya.

Setelah itu beliau pulang dan menuju kerumah, maka turunlah wahyu yang menegur sikapnya rasul tersebut. Yang termaktub dalam Al-Qur'an Surat 'Abasa Ayat 1-4 turun sesudah surat An-Najm:

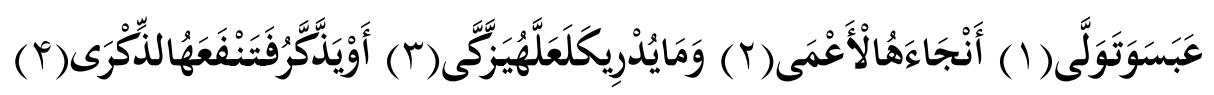

Artinya:

(1)Dia (Muhammad) berwajah masam dan berpaling, (2) karena seorang buta telah datang kepadanya (Abdullah bin Ummi Maktum), (3) Dan taukah engkau (Muhammad) barangkali dia ingin menyucikan dirinya (dari dosa), (4) atau dia (ingin mendapatkan pengajaran, yang memberi manfaat kepadanya? ${ }^{13}$

\footnotetext{
${ }^{12}$ Hamka. 2015. Tafsir Al-Azhar Juz Amma. Jakarta : Gema Insani

${ }^{13}$ Al-Qur'an. Al haram Al-Qur'anTranselitrasi Per Kata danTajwidBerwarnaEdisi 1Tahun 2016.

Yogyakarta: PT. Iqro Indonesia Global
} 
Senada dengan tafsir Al-azhar, tasir Jalalain juga mengisyaratkan hal yang sama.Dalamsurat 'Abasa عبس(dia telah bermuka masam) yakni Muhammad telah bermuka masam- وتولّلى (dan berpaling) yaitu memalingkan mukanya karena, اعمبان خاءه(telah datang seorang buta kepadanya) yaitu Abdullah bin Ummi Maktum. Nabi SAW. Tidak meladeni nya pada saat itu ia sedang sibuk menghadapi orangorang yang di harapkan untuk dapat masuk Islam, ${ }^{14}$. Setelah itu, bila mana datang Abdullah bin Ummi Maktum berkunjung kepadanya, beliau selalu mengatakan: "Selamat datang orang yang menyebabkan Rabbku menegurku karenanya", lalu beliau menhamparkan kain serbanya sebagai tempat duduk Abdullah bin Ummi Maktum.

Ayat 3 dan 4 juga berkaitan (3) Dan taukah engkau (Muhammad) barangkali dia ingin menyucikan dirinya (dari dosa), (4) atau dia (ingin mendapatkan pengajaran, yang memberi manfaat kepadanya?

Dengan kedua ayat ini Rasulullah SAW. Diberi ingat oleh Allah, bahwa Ibnu Ummi Maktum lebih besar harapanya akan berkembang lagi menjadi seorang yang saleh seseorang yang bersih hatinya, walaupun buta. Karena buta kalau jiwa bersih kebutaan tidaklah akan menghambat kemajuan iman seseorang. Bayangkan saja betapa halus perkataan itu dari Allah seorang cacat jasmaninya dalam keadaan buta, tetapi dapat lebih maju dalam iman, adalah salah satu pujian bagi Ibnu Ummi Maktum. Dan orang pun melihat sejarah gemilang beliau sehingga di dalam sebuah riwayat dari Qatadah, yang diterimanya dari Anas bin Malik, bahwa di zaman pemerintahan Amirul mukminin Umar bin Khatab, Anas melihat dengan matanya sendiri, Ibnu Ummi Maktum turut dalam peperangan hebat di Qadisiyah, ketika penaklukan Negeri Persia, dibwah pimpinan Sa'ad bin Abu Waqqash ${ }^{15}$

Kisah dari Abdullah bin Ummi Maktum akan menambah khazanah pengetahuan kita bersama. Teguran Allah karena tidak memperhatikan kaum difabel secara serius. Hal tersebut akan menjadi bekal umat islam untuk lebih

\footnotetext{
${ }^{14}$ Tafsir Jalalain. 2012. Terjemahan Tafsir Jalalain Jilid 4 berikut Asbaabun Nuzulnya oleh Imam Jalaludin Al-Mahali dan Imam Jalaludin As-Suyuti . Bandung: Sinar Baru Algensindo Hal 2657

${ }^{15}$ Hamka. 2015. Tafsir Al-Azhar Juz Amma. Jakarta : Gema Insani
} 
memperhatikan orang-orang difabel dalam berbagai bentuk keadaan, mereka membutuhkan uluran tangan kita semua untuk berkembang. Tanpa adanya supporting dari berbagai macam element masyarkat dan pemerintah mereka akan stagnan(berhenti)tetap terus menutup diri, dari berbagai lingkungan masyarakat

Maka dari itu sudah seharusnya masyarakat dan pemerintah bersatu memberikan bantuan. Perlunya penyadaran, mengerti bagaimana perasaan yang dirasakan oleh difabel selama ini ketika mendapat diskriminasi. Menggugahqalb (hati) setiap umat muslim untuk ikut merasakan, apa yang mereka rasakan supaya memahami perasaan yang mereka hadapi selama ini.

\title{
Mendisabilitaskan Manusia
}

Berangkat dari kisah Rasulullah memperlakukan kaum difabel, seharusnya manusia memang harus memandang sama derajatnya, karena Allah sejatinya tak pernah memandang akan rupa dan bentuk fisiknya seperti Surat Al-Hujurat ayat 13:

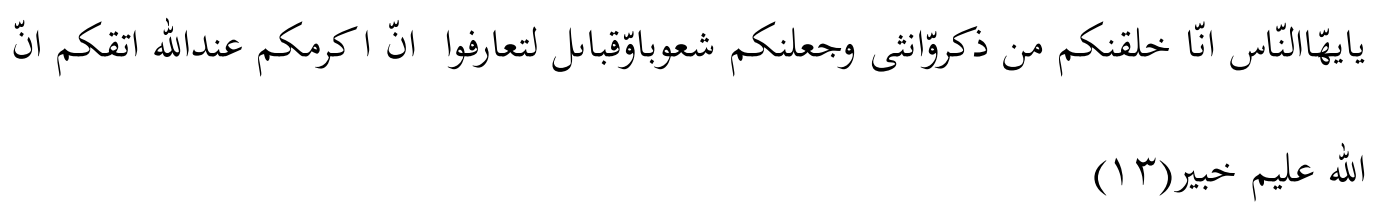

\begin{abstract}
Artinya:
Wahai manusia sungguh, kami telah menciptakan kamu dari seorang laki-laki dan seorang perempuan, kemudian kami jadikan berbangsa-bangsa dan bersukusuku agar kamu saling mengenal. Sungguh, yang paling mulia diantara kamu di sisi Allah ialah yang paling bertakwa. Sungguh, Allah Maha Mengetahui, Maha teliti. $^{16}$
\end{abstract}

Ayat tersebut menjelaskan dan membuka mata kita akan pentingnya takwa, karena sesungguhnya telah nampak dari sifat yang baik, dekat dengan Allah dengan memperbanyak ibadah dan dzikir itu lah yang paling baik di sisinya. Hadist riwayat bukhari muslimpun juga menjelaskan manusia yang mulia derajatnya tidak dilihat

\footnotetext{
${ }^{16}$ Al-Qur'an. Al haram Al-Qur'anTranselitrasi Per Kata danTajwidBerwarnaEdisi 1Tahun 2016.

Yogyakarta: PT. Iqro Indonesia Global
} 
dari rupa atau bentuk tubuhnya. Namun hati yang bersih dari suatu mudharat itu lah yang dicari.

Dari kitab Imam Al-Ghazali : Ihya Ulumudin Jilid III, kita di perintahkan untuk selalu tunduk kepada Allah:

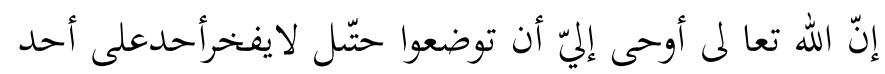

\section{Artinya:}

"Sesungguhnya Allah Ta'ala menurunkan wahyu kepadaku: bahwa merendahkan dirilah kamu, sehingga tiada menyombongkan seseorang terhadap seseorang ",17

Supaya tidak menjadi sombong perlulah berserah diri kepada Allah, nanti akan dapat menghormati sesama insan manusia. Manusia memang seharusnya seperti itu tidak membanggakan diri karena memiliki segalanya apalagi memberikan stigma kepada masyarakat yang mempunyai kecacatan. Hal tersebut tidak akan di sukai oleh Allah SWT.

Manusia perlu merefleksikan diri memahami betul siapa yang disabilitas selama ini, apakah orang yang mempunyai kekurangan fisik telinga tidak bisa mendengar, mata tidak bisa melihat, dan mulut tidak bisa berbicara. Hal tersebut harus dimaknai dengan betul. Allah telah menjelaskan secara jelas tentang makna tersebut dalam surat Al-Baqarah ayat 18:

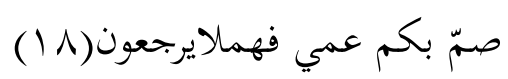

Artinya:

Mereka tuli, bisu dan buta sehingga mereka tidak dapat kembali.

Dalam Tafsir Jalalain jilid 1 di jelaskan tentang bagaimana makna dari ayat tersebut ص ص ص (mereka tuli) terhadap kebenaran, maksudnya tidak mau menerima kebenaran yang didengarnya-بكم (bisu) terhadap kebaikan hingga tidak mampu mengucapkanya عمي(buta) terhadap jalan kebenaran dan petunjuk Allah sehingga tidak dapat melihatnya ${ }^{18}$

\footnotetext{
${ }^{17}$ Al-Ghazali, Imam. 1986. Kitab Ihya Ulumudin Jilid III terjemahan Ismail Yakub. Jakarta: C.V Faizan

${ }^{18}$ Tafsir Jalalain. 2012. Terjemahan Tafsir Jalalain Jilid 1 berikut Asbaabun Nuzulnya oleh Imam Jalaludin Al-Mahali dan Imam Jalaludin As-Suyuti . Bandung: Sinar Baru Algensindo Hal 9
} 
Senada dengan tafsir Jalalain, tafsir Al-Maraghi Allah menyatakan sifat-sifat tersebut untuk mereka. Sekalipun alat-alat indra mereka masih tetap normal, bisa mendengar berbicara tak bisa memanfaatkan sebaik mungkin ${ }^{19}$. Dengan kata lain mereka menutup diri akan nasihat-nasihat yang baik tak mau mendengar hal yang baik, tidak memahami maksudnya akan tetapi seolah-olah menjadi orang yang mendengar. Mereka juga kehilangan lisanya, karena mereka tidak mau mengucap kata-kata hikmah (hal yang baik), tak pernah bertanya dalam menghadapi suatu kesulitan yang mereka hadapi, sama saja dengan bisu karena tidak bisa memanfaatkan lisanya. Hilang nya penglihatan karena tidak bisa melihat masalah yang menimpa masyarakat di sekitarnya. Jelasnya, semua indra yang ada pada diri mereka tak berfungsi sebagaimana mestinya.

Dapat disimpulkan orang cacat fisik bukanlah orang yang kekurangan dalam indra penglihatanya, namun orang yang buta, tuli dan bisu orang yang tak mampu melihat kondisi di masyarakat, hanya terdiam ketika menghadapi suatu masalah. Lisannya tak bergerak, matanya tertutup materialisme, telinganya di pergunakan mendengar tapi seolah tak bergeming melihat permasalahan disabilitas.

Mereka tenggelam dalam ambang kebingungan dan kesesatan tak sadar apa yang telah mereka perbuat. Sebab siapapun telah kehilangan alat indranya karena tak mempergunakan semestinya. Kaum minoritas sangatlah perlu di perhatikan terlepas akan kecacatan yang mereka sandang, sudah saatnya hati ini tergugah dengan banyak hal yang sudah mereka alami. Masyarakat pemerintah dan berbagai element masyarakat tidak memandang remeh kaum difabel. Karena sejatinya Allah menciptakan semua mahluk hidup dalam keadaan sempurna, (dalam keadaan sebaikbaiknya) yang sudah di jelaskan Al-Qur'an surat At-tin ayat 4:

$$
\text { لقدخلقناالانسان في ا حسن تقويم (†) }
$$

Artinya:

Sungguh, kami telah menciptakan manusia dalam bentuk sebaik-baknya. ${ }^{20}$

\footnotetext{
${ }^{19}$ Tafsir Al-Maraghi. 1992. Terjemahan Tafsir Al-Maraghi Jilid 1 oleh Ahmad Mushthafa. Semarang: PT. Karya Toha Putra Hal 95

${ }^{20}$ Al-Qur'an. Al haram Al-Qur'anTranselitrasi Per Kata danTajwidBerwarnaEdisi 1Tahun 2016.

Yogyakarta: PT. Iqro Indonesia Global
} 
Allah telah memberikan sinyal (pertanda) manusia memang diciptakan dalam keadaan sebaik-baiknya mahluk hidup, fatamorgana (awang-awang) yang dilihat selama ini bahwa Allah menciptkan manusia dengan berbeda-beda dan tidak sempurna adalah suatu kesalahan. Karena sempurna menurut prespektif (pandangan) manusia dengan pandangan Allah tentang kesempurnaan sangatlah berbeda.

Sudah seharusnya kita berhenti membicarakan kejelekan dan kekurangan difabel. Pemberian hak kesetaraan bagi merekalah yang saat ini dibutuhkan, memberikan sumbangsih bagaimana menciptakan sebuah rumah ibadah yang inklusi yang terjangkau bagi kaum difabel maupun manusia reguler (normal). Akses tersebut akan memberikan kepercayaan masyarakat difabel untuk menampakan diri di lingkungan masyarakat, yang sebelumnya enggan untuk berkunjung ke rumah ibadah.

\section{Inklusi Menjadi Kesetaraan Aksesibilitas Rumah Ibadah Bagi Kaum Difabel}

Aksesibilitas adalah derajat kemudahan yang dicapai oleh seseorang terhadap suatu objek pelayanan ataupun lingkungan difokuskan pada pengguna orang cacat, untuk menggunakan fasilitas seperti kursi roda yang bisa berjalan di trotoar dan sebagainya. Kemudahan yang disediakan bagi penyandang cacat atau lansia masuk dalamPeraturan pemerintah pekarjaan umum tahun 2006 No. 30/PRT/M/200 Bab 1 Ketentuan umum pasal 1 ayat (3) masyarakat harus ikut andil dalam menjamin akses penyandang cacat terhadap lingkungan fisik, transportasi, dan fasilitas yang menunjang peribadahan ${ }^{21}$. Dan setiap anggota masyarakat mempunyai hak dan kewajiban yang sama untuk turut serta dalam pembangunan ${ }^{22}$

Kemudian dalam membuat peta konsep rancangan bangunan tentunya melibatakan banyak faktor dari : estetika, pilihan tehnik, masalah keamanan, dan biaya renovasi. Karena tidak serta merta membangun sebuah masjid tanpa adanya pertimbangan yang matang. Arsitektur bangunan yang di renovasi menuntut untuk,

\footnotetext{
${ }^{21}$ Peraturan Menteri Pekerjaan Umum. 2006. Aksesibilitas dan Fasilitas bagi lansia dan penyandang cacat. Jakarta

${ }^{22}$ Pratimatari, Uning. 2009. Jaminan Aksesibilitas Bagi Penyandang Cacat Sebagai perwujudan

Perlindungan Hak Asasi Manusi. Bandung: Refika aditamaHal 253
} 
dapat digunakanya semua orang termasuk orang difabel maupun masyarakat pada umumnya. Renovasi tersebut bertujuan untuk menyamaratakan antara orang normal dan cacat supaya tidak ada belengu sekat antara kedua belah pihak. Dan hal tersebut sudah sesuai dengan, Hadist Al-Bukhori untuk meremajakan masjid (rumah Allah) disebutkan tentang membangun (merenovasi) tempat ibadah:

$$
\begin{aligned}
& \text { حديث عثمان بن عفّان, عن عبيدا الله ا لخولانيّ, أنهُ سمع عثْمان بن عفا ن يقول عند قول النّا س } \\
& \text { فيه حين بنى مسجدالرّسُول : إنكُم أكشرتم, وإِي سمعت النبي يقولُ : من بنى مسجدًا يبتغي به } \\
& \text { وجه الله, بنى الله له مثلهُ في الجنّة }
\end{aligned}
$$

Diriwayatkan: dari'Utsman bin 'Affan, dari 'Ubaidillah Al-Khaulani, sesungguhnya ia mendengar 'Utsman bin'Affan berkata ketika orang-orang berkata tentangnya, yaitu ketika ia merenovasi Masjid Rasul 'Sesungguhnya kalian banyak (berkata-kata), sesungguhnya aku mendengar Nabi bersabda, "Barang siapa yang membangun (merenovasi) sebuah masjid dengan mengharapkan ridha Allah SWT. Allah pasti membangunkan untuknya yang seperti itu di Surga". (Disebutkan oleh Al-Bukhari pada kitab ke-8 kitab shalat, bab ke-65 Bab orang yang membangun Masjid $)^{23}$

Makna dari hadist tersebut Merenovasi sebuah masjid Rasulullah : yaitu membangunya dengan batu yang berukir dan tiang-tiang dari batu serta mengatapinya dengan kayu. Itu terjadi pada tahun tiga puluh hijriyah. Yang dimaksud membangun disini bukan membangun kembali, melainkan memperluas dan menguatkan nya supaya lebih baik lagi. Dalam hadist tersebut memang disebutkan untuk membangun masjid tapi arti lebih dalam adalah bagaimana memberikan sentuhan baru merenovasi (design) supaya sesuai dengan kondisi lingkungan sekitar. Supaya masyarakat datang berbondong-bondong ke masjid untuk menjalankan peribadahan, secara layak dan terhormat.

Memberikan fasilitas dan rancangan bangunan sebagai bentuk orientasi dan mobilitas difabel, proses penggunaan semua indra yang masih ada (dapat digunakan)

\footnotetext{
${ }^{23}$ Abdul Baqi, Muhammad Fu'ad. 2010. Al-lu'luwalMarjan Kumpulan HadistShahih Bukhari Muslim. Solo: InsanKamil Hal 930
} 
terhadap benda-benda yang penting yang ada di sekitarnya ${ }^{24}$. Memanfaatkan indra yang masih berfungsi supaya mudah memberikan rancang bangun. Tentunya orientasi tersebut didasarkan kepada ketunaan yang masih bisa terjangkau (cacat fisik) tunanetra, tunadaksa, tunarungu.

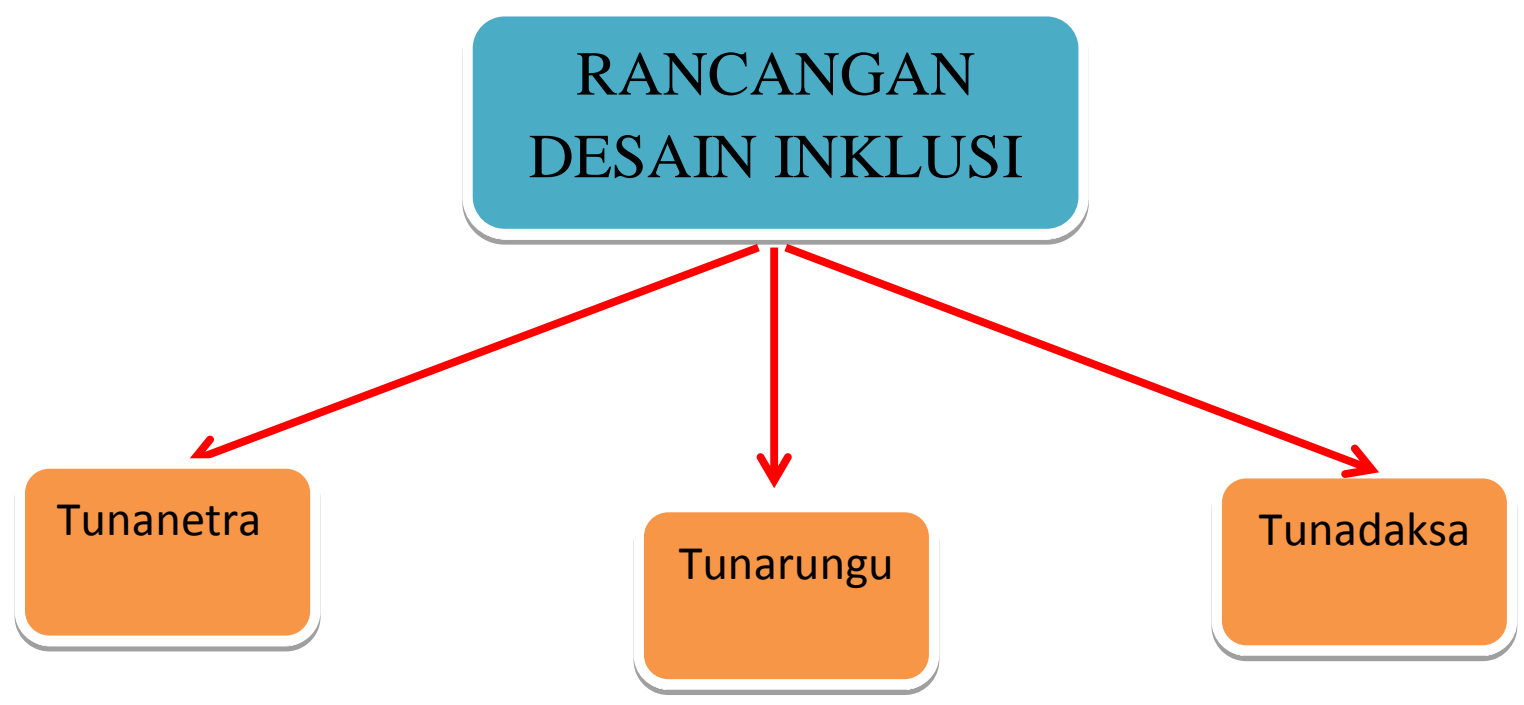

Gambar 1. Rancangan Desain Inklusi

(1)Dipandang dari sudut pandang bahasa, Istilah tunanetra berasal dari kata tuna dan netra. Tuna berarti luka atau rusak, netra berarti mata ${ }^{25}$. Kecacatan pada bagian mata. Rancangan yang perlu diberikan oleh cacat netra harus memberikan rangsangan pada sistem perabaan dan pendengaran. Bentuk hurufhuruf brille, pada tempat-tempat tertentu seperti kamar mandi, awal pintu masjid, tembok yang di beri plat brille, jalan yang diberi landasana untuk berjalan difabel menggunakan tongkat. Dan ditambah sistem suara yang memberikan sirine/aba-aba bila mana tunanetra tidak mengetahui ruangan masjid.

(2) Tunarungu secara fisik, berbeda dengan yang orang dari umumnya, mereka susah untuk berbicara (kurang jelas) artikulasinya dan bahkan tidak dapat

\footnotetext{
${ }^{24}$ Wahyono, Endro. 2013. Orientasi dan Mobilitas. Malang: Universitas Negeri Malang Hal 9

${ }^{25}$ Rusak mata tidak dapat melihatWahyono, Endro. 2013. Orientasi dan Mobilitas. Malang: Universitas Negeri Malang Hal 1
} 
berbicara sama sekali, mereka hanya berkomunikasi dengan isyarat ${ }^{26}$. Bentuk design arsitektural yang cocok ialah mengedepankan pada visual dan oral. Bentuk tempat-tempat yang ada di peribadahan bisa menggunakan tanda-tanda berupa bahasa isyarat (visual) supaya mereka mengerti, mana saja tempat yang ingin dituju. Selanjutnya bahasa isyarat tersebut bisa digunakan saat ada ceramah di masjid, agar tunarungu pun juga bisa mengerti apa yang disampaikan oleh khotib saat melakukan ceramah di masjid.

(3) Tunadaksa berasal dari kata "Tuna" yang berarti rugi dan "Daksa" berarti tubuh $^{27}$. Cacat tubuh atau kerusakan tubuh yang menyebabkan tidak bisa berjalan dan harus menggunakan kursi roda dalam menjalankan mobilitas nya. Untuk telingan, mulut, dan mata tidak mengalami masalah namun pada bagian organ tubuh kaki, tangan, badan. Perlunya design bidang miring yang di sesuaikan pada tangga ke masjid. Supaya lebih mudah untuk memasuki masjid. Tambahan design arsitektural pada kamar mandi menyesuaikan dengan kebutuhan, seperti tidak terlalu tinggi, mudah untuk dilewati kursi roda. Supaya lebih aksesibel bagi difabel.

Harapanya design dan bentuk arsitektural tersebut dapat menjadi solusi ketimpangan yang terjadi, membuat mereka keluar dapat merasakan berkumpul bersama orang reguler (normal). Tanpa adanya hambatan apapun yang mengurangi hak-hak difabel dalam menjalankan kehidupan selayaknya. Menjunjung tinggi kemartabatan dan menggap mereka mempunyai kesempatan yang sama dalam menunaikan peribadahan

\section{Konklusi: Menguggah Empati Dan Kesetaraan Bagi Difabel}

Sudah seharusnya manusia menolong sesama manusia tidak memandang jabatan, status dan bentuk rupanya, selayaknya mampu memandang harkat dan

\footnotetext{
${ }^{26}$ Tunarungu mempunyai intensitas pengdengaran yang berbeda-beda 70 decibel bisa dikatakan tuli (deaf) Effendi, Mohammad. 2010. Suplemen Informasi Layanan Pendidikan Anak berkebutuhan Khusu. Malang: Univesitas Negeri Malang Hal 26

${ }^{27}$ Orang yang mengalami cacat pada bagian tubuh disebut tunadaksa Effendi, Mohammad. 2010. Suplemen Informasi Layanan Pendidikan Anak berkebutuhan Khusu. Malang: Univesitas Negeri Malang Hal 38
} 
martabat seseorang bukan dari covernya. Empati perlu di pupuk, hati perlu dibuka membuka mata akan mereka yang mendapat diskriminasi yang seharusnya tak terjadi. Menggugah hati nurani merasakan apa yang mereka rasakan, membuang masa lalu yang kelam. Sejarah hidup difabel perlu dirubah, Islam sebagai ujung tombak untuk memerdekakan mereka, memberikan hak yang semestinya.

Pemberian fasilitas dan aksesibilitas yang sesuai dengan masyarkat difabel demi memberi kesetaraan dan kesejahteraan. Tempat ibadah yang inklusi membuat semua orang bisa untuk datang ke masjid tanpa adanya perbedaan. Masyarakat ikut andil serta dalam menciptakan sebuah generasi (tatanan baru) yang inklusi, meleburkan segala sekat yang menghalangi antara difabel dan masyarakat reguler.

\section{DAFTAR PUSTAKA}

Abdul Baqi, Muhammad Fu'ad. 2010. Al-lu'lu wal Marjan Kumpulan Hadist Shahih Bukhari Muslim. Solo: Insan Kamil

Al-Ghazali, Imam. 1986. Kitab Ihya Ulumudin Jilid: III terjemahan Ismail Yakub. Jakarta: C.V Faizan

Al-Qur'an. Al Haram Al-Qur'an Transelitrasi Per Kata Dan Tajwid Berwarna Edisi 1Tahun 2016. Yogyakarta: PT. Iqro Indonesia Global

Asrori, Hadi. 2009. HAM Dalam Perspektif Agama Islam. Bandung: Refika aditama

Aziz, Safrudin. 2014. Perpustakaan Ramah Difabel. Yogyakarta: Ar-Ruzz Media

Badan Pusat Statistika. 2010. Jumlah Penyandang Cacat di Indonesia. Jakarta

Effendi M \& Evandri Taufani S. HAM Dalam Dimensi/Dinamika Yuridis, Sosial, Politik Dan Proses Penyusunan/Aplikasi HA-KHAM (Hukum Hak Asasi Manusia) Dalam Masyarakat. Bogor: Ghalia Indonesia

Effendi, Masyhur.1993. Dimensi/Dinamika Hak Asasi Manusia Dalam Hukum Nasional dan Internasional. Bogor: Ghalia Indonesia

Effendi, Mohammad. 2010. Suplemen Informasi Layanan Pendidikan Anak berkebutuhan Khusu. Malang: Univesitas Negeri Malang

Naning, Ramdlon. 1983. Cita dan Citra Hak-hak Asasi Manusia di Indonesia. Jakarta: Lembaga Kriminolog Universitas Indonesia

Nasution, Bahder J. 2014. Negara Hukum dan Hak Asasi Manusia. Bandung: Mandar Maju

Pedoman Penulisan Karya Ilmiah. 2017. Tugas Akhir Skripsi Tesis Disertasi Makalah Artikel Laporan Penelitian. Malang: Universitas Negeri Malang

Peraturan Menteri Pekerjaan Umum. 2006. Aksesibilitas dan Fasilitas bagi lansia dan penyandang cacat. Jakarta 
Pratimatari, Uning. 2009. Jaminan Aksesibilitas Bagi Penyandang Cacat Sebagai perwujudan Perlindungan Hak Asasi Manusia. Bandung: Refika aditama

Sholeh, Akhmad.2016. Aksesibilitas Penyandang Disabilitas Terhadap Perguruan Tinggi. Yogyakarta: LKIS

Tafsir Al-Maraghi. 1992. Terjemahan Tafsir Al-Maraghi Jilid 1 oleh Ahmad Mushthafa. Semarang: PT. Karya Toha Putra

Tafsir Jalalain. 2012. Terjemahan Tafsir Jalalain Jilid 1 berikut Asbaabun Nuzulnya oleh Imam Jalaludin Al-Mahali dan Imam Jalaludin As-Suyuti . Bandung: Sinar Baru Algensindo

Tafsir Jalalain. 2012. Terjemahan Tafsir Jalalain Jilid 4 berikut Asbaabun Nuzulnya oleh Imam Jalaludin Al-Mahali dan Imam Jalaludin As-Suyuti . Bandung: Sinar Baru Algensindo

Tim Indepth Rights PPRBM Yayasan Bhakti Luhur. 2016. Equality Hak-hak Penyandang Disabilitas. Malang: Caesarya Yudiswar

Wahyono, Endro. 2013. Orientasi dan Mobilitas. Malang: Universitas Negeri Malang

Winata, Darwin. 2010. Kamus Saku Ilmiah Populer. Malang: Gama Press 
